\title{
sciendo AUDIT AS A TOOL TO CONTROL THE FUNCTIONALITY OF SHIPS SAFETY MANAGEMENT SYSTEMS
}

DOI 10.2478/ntpe-2018-0077

\author{
MSc. Elżbieta Wojniłko \\ Maritime University of Szczecin, Poland
}

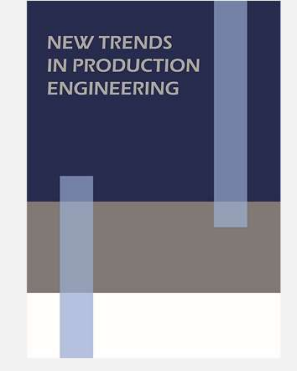

2018

Volume 1

Issue 1

pp. $615-621$

\begin{abstract}
The aim of this paper is to assess whether audit may be recognised as the evaluation tool for management systems in terms of their functioning and ensuring constant improvement. The paper content refers to the role of both internal and external audit. It also includes a characteristic of an internal auditor as a person directly responsible for efficient and effective audit. A correlation between the management system and the management process based on the guidelines is a subject of the analysis, too. The paper includes also the presentation of the safety management system and ship energy efficiency management systems the implementation of which is obligatory at ships. However, they differ in the methodology of the efficiency assessment. The author analysed the data previously collected and the information obtained during interviews with individuals to whom were delegated the duties in the scope of the both management schemes. The possibility of the using audit as a tool to improve the energy efficiency of ships is also considered hereunder. A proposed solution that may be applied to develop detailed standards in terms of the ship energy efficiency management process is also included.
\end{abstract}

Keywords: safety management systems, ship audit, evaluation of the functioning of the system, ISM Code, energy efficiency

\section{SAFETY MANAGEMENT SYSTEM}

The International Management Code for the Safe Operation of Ships and for Pollution Prevention (the International Safety Management (ISM) Code) was adopted by the International Maritime Organization (IMO) by the Resolution A.741 (18) and has been in force since $1^{\text {st }}$ January 1998. The ISM Code is included in the provisions of chapter IX of the International Convention for the Safety of Life at Sea (SOLAS). As from 1 July 1998, it became applicable to passenger ships, high-speed passenger ferries, tankers, chemical tankers, gas tankers, bulk carriers and high-speed cargo vessels of 500 gross tonnage (GT) and above. On $1^{\text {st }}$ July 2002, the ISM Code provisions became mandatory for the remaining cargo vessels and mobile offshore drilling units of 500 gross tonnage (GT) and above. The only vessels that are not obliged to implement the safety management systems are the ships providing government noncommercial services (IMO, 1974).

The ISM Code is an international standard for safe ship management and pollution prevention. The requirement imposed by the ISM Code is that the Company shall establish objectives as described in section 1.2 of the ISM Code, and addition that the Company shall develop, implement and maintain a Safety Management System (SMS) which includes functional requirements as listed in section 1.4. of the ISM Code. The idea of the ISM Code is to support and encourage the development of a safety culture in shipping as well as the environment protection. The objectives of the mandatory implementation of the ISM Code are to ensure the compliance with mandatory rules and regulations related to safe operation of ships and environment protection, and effective implementation and enforcement thereof by the Administrations (PRS, 2005).

To comply with the requirements of the ISM Code, Company should develop, implement and maintain a safety management system to ensure that the safety and environmental protection policy of the Company are implemented. The safety management systems adopted on ships 
should ensure full safety during ship operation and exploitation, safe work conditions for every crewmember with special attention to the environment protection. The three general objectives of the safety management are:

- to provide for safe practices in ship operation and a safe working environment;

- to assess all identified risks to its ships, personnel and the environment and establish appropriate safeguards;

- to continuously improve safety-management skills of personnel ashore and aboard ships, including preparing for emergencies related both to safety and environmental protection.

These objectives provide clear guidelines to Companies for the development of safety management systems elements (PRS, 2005).

The number of operations related to the cargo handling is significant on the ship belonging to the commercial fleet. This results in the expansion of the SMS documentation. In order to reduce bureaucracy and to make it easier and faster to find a procedure or an instruction specifying a particular action to be undertaken, Companies provide an electronic version of the documentation. Such a solution prevents outdated documents from being used since the SMS is updated online from an ashore office of the Company. It also is helpful in finding specific requirements and provisions related thereto. The results of the questionnaire carried out among the crew and employees of a Company showed that despite the requirements imposed by the safety management system, they recognise the systems as needed and affecting the safety improvement. When asked whether the safety management system contributed to improving safety and environmental protection, $87 \%$ of them responded that it corresponded to its role (Fig. 1).

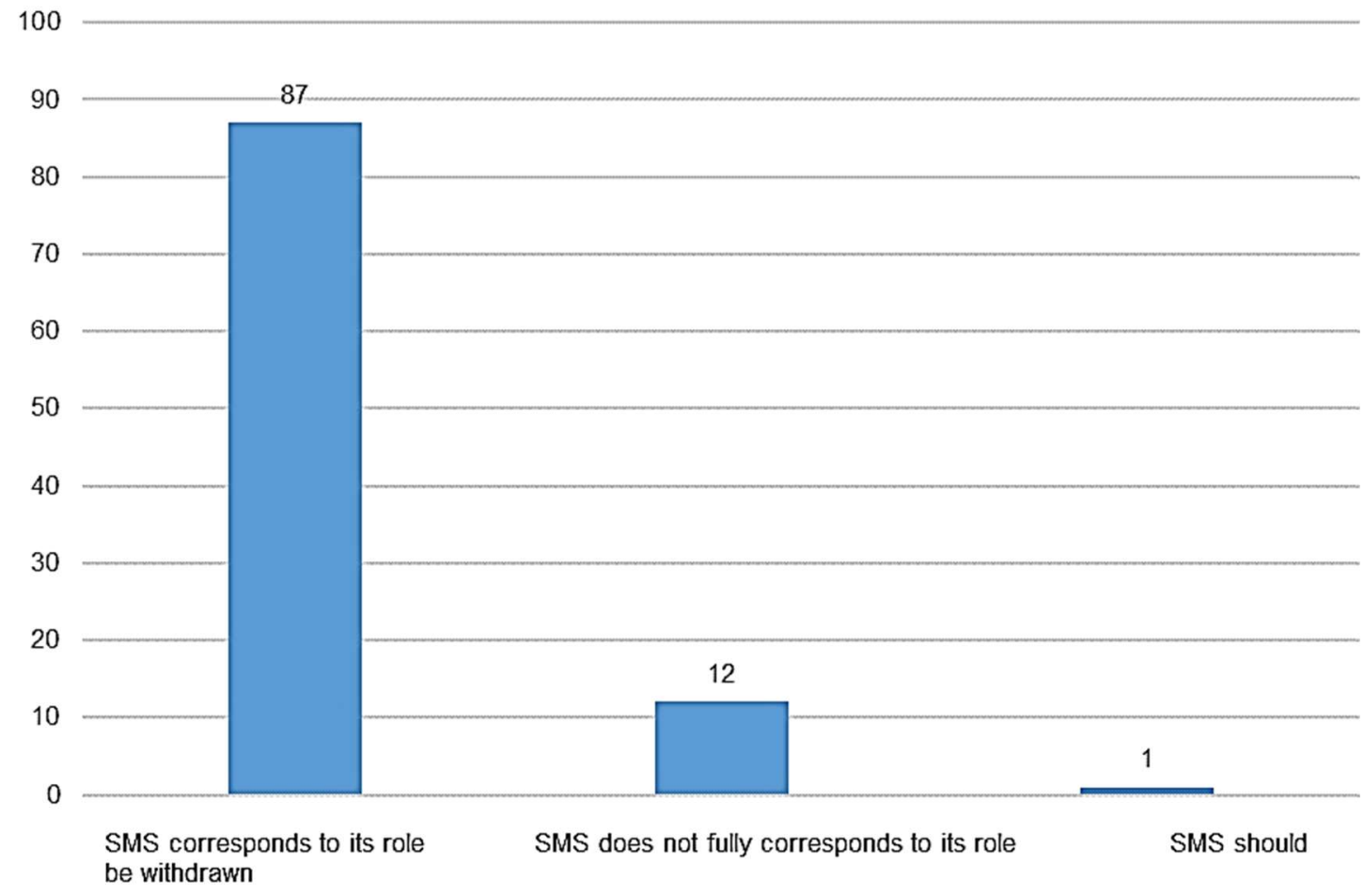

Fig. 1. Percentage share of answers to questions about the role of the safety management system.

Source: Author's elaboration.

According to the ISM Code requirements, a safety management system must be submitted for certification process by each Company. As a result of that procedure, a Company shall obtain a document issued by the Administration, or by an organization recognized by the Administration or, at the request of the Administration proving that the systems' functions in the Company offices and on their ships. The documents mentioned above are the Document of Compliance (DOC) and the Safety Management Certificate (SMC). 
The Document of Compliance is issued to the Company for the ships that are operated by them. It means that separate DOCs are issued for each ship type owned by the Company. The Document of Compliance is issued by the government of the state whose flag the ship is entitled to fly, on the successful completion of the assessment of the Company offices and on their ships. The Safety Management Certificate is issued upon having the safety management system verified in terms of its compliance with the ISM Code.

The Certificate may be issued if:

- the Company holds full-term DOC (not interim) for a particular ship type;

- the system is compliant with the requirements of a classification society;

- the requirements of the Administration of the flag state are met.

The Safety Management Certificate shall not be issued, confirmed or renewed if major nonconformities have not been removed and re-verification in terms of certification audit has not been carried out. The Safety Management Certificate should be issued for a period not exceeding five years 5 years from the date of the audit completion with the obligation to prove its validity minimum once during an interim audit. A copy of the certificate should be available at the Company head office (PRS, 2006).

\section{SHIP ENERGY EFFICIENCY MANAGEMENT}

The ship energy efficiency management is aimed at the optimization of energy consumption on a ship which should result in measurable economic and ecological benefits. In the economic aspect, it should lead to the reduction of operational costs by minimizing energy losses in every operational area of the ship. In terms of the environment protection, the process should contribute to the reduction of the $\mathrm{CO}_{2}$ emission. For this purpose, the following control tools have been introduced:

- the Energy Efficiency Design Index (EEDI),

- the Energy Efficiency Operational Indicator (EEOI),

- the Ship Energy Efficiency Management Plan (SEEMP).

Currently, the requirements for the above tools are separate guidelines, but the idea for their implementation is focused on the same objective. The conclusion is that the ship energy efficiency management process constitutes a legal requirement, but is not standardised.

Since $1^{\text {st }}$ January 2013, the energy efficiency management plan application has become obligatory. The objective of the SEEMP is to strive for increased energy efficiency of a vessel and the devices and equipment installed thereon by the implementation of the developed activities. The SEEMP is a management tool to assist companies in managing the energy efficiency of their ships. It has not been yet fully verified and its structure is focused on planning, implementation, monitoring, and assessment of the results (Jurdziński, 2013). No system regulations exists.

Given that there is a standard ISO 50001:2011 which specifies requirements for establishing, implementing, maintaining and improving an energy management system, it may be considered both as a superstructure of the mandatory ship energy efficiency management plans and as an established tool or mechanism to improve the ship energy efficiency. The standard may be useful in systems' management in order to maximise their energy efficiency. However, it is possible that the standard, as it is, will not be suitable for the functions of the ship. Therefore, it would be reasonable to consider developing an energy efficiency management system joining current framework and focused on the ship operational specification in terms of the ships' types and their functions.

\section{AUDIT AS A TOOL}

According to the definition included in ISO 19011, an audit means a systematic, independent and documented process for obtaining audit evidence and evaluating it objectively to determine the extent to which the audit criteria are fulfilled. The audit objective is to control whether the undertaken activities are compliant with the content of the system documentation and if it will ensure safety on a ship and prevent the environment against pollution. An auditor during the 
audit verifies whether the procedures, which result from the law in force and have been introduced by the flag state, are respected. Audit follow-up may be translated into improved organisational activities mainly by implementing changes in the safety management system being a result of the internal audit. A value added of an internal audit is an advisory function of the auditor. However, it is justified only if the auditor has adequate knowledge of the merits. The safety management system distinguishes two audit categories: internal audit performed by Company employees and an external audit carried out by inspectors of the flag state or the entitled organisation. During the inspections performed by the flag state, a passenger ferry or a vessel other than passenger ferry of 500 gross tonnage (GT) and above, practicing international shipping, are subject to the following audits:

- initial audit - which is carried out in order to issue a Safety Management Certificate or an interim document;

- intermediate audit - which is carried out to maintain the validity of the Safety Management Certificate;

- renewal audit - which is carried out in order to issue a new Safety Management Certificate due to expiry of its validity period;

- additional audit - which is carried out for additional verification how the SMS functions and is performed between the audits.

The Company is subject to the following audits:

- initial audit - which is carried out in order to issue a Document of Compliance or an interim document;

- annual audit - which is annually carried out to maintain the validity of the Document of Compliance. It should be performed within three months before and after each anniversary date of the Document of Compliance.

- renewal audit - is to be performed in order to issue a new Document of Compliance due to expiry of its validity period;

- additional audit - which is carried out for additional verification how the SMS functions and is performed between the audits (Journal of Laws, 2016).

According to the research, the most effective element of the safety management system on a ship, enabling verification whether the activities in terms of safety and pollution-prevention are compliant with the safety management system, is an annual internal audit. Its objective is to control if the activities specified in the documentation are actually executed. However, the efficiency of that tool, to the large extent, depends on the auditor himself.

\section{AUDITOR COMPETENCES}

Every auditor should be guided by six rules during the audits. The first one refers to reliability involving the performance of the work in the honest, conscientious and responsible manner, the compliance with all applicable legal requirements, and the demonstration of competence and impartiality in the performance of his / her work and not being subject to any influence that may affect the assessment during the audit. The second rule states that the auditor should present reasonable results which shall mean reflecting the auditing activities exactly and truthfully. The auditor must base their considerations on documented information, not on speculations. If the auditor is not certain about the information, he/she should not refer to it in the report. The third rule mentions due diligence. It should be understood as diligence and common sense during auditing which ought to be considered as a rational judgment in all audit situations. Fourthly confidentiality. The auditor should demonstrate discretion and protect the information to which he/she has an access. The information must not be used for achieving personal benefits by the auditor or in a manner detrimental to the legitimate interests of the auditee. The fifth rule refers to being independent which ensures impartiality of the audit and objectivity of the audit findings. The internal auditor may not be placed in a situation in which the effects of his/her work or opinions may be subject to any doubt (PKN, 2012, Milewska-Zawada, 2016). The ISM Code, Part A Implementation, Section 12.5 specifies that personnel carrying out audits should be independent of the area being audited unless this is impracticable due to the size and the nature 
of the Company (IMO, 1995). The internal auditor should be independent of the operational managers who are responsible for the audited area. He/she should report to the management level that enables the auditor to perform the assigned tasks. In the companies, the auditors are usually persons acting as a designated person, superintendent (but only if the person is not responsible for day-to-day ship operation) or an employee responsible for safety management systems.

In the opinion of the crewmembers holding management functions, professionalism and objectivity of the auditor are the most significant characteristics that add value to the audit. If the auditor establishes relations with others without difficulty, he/she is communicative and has the ability to work in the multicultural environment, then the results of their work would be highly assessed and appreciated both by the ship management and the Company.

The below Figure presents the percentage share of particular responses to the question whether an internal audit would bring the added value to the safety management system.

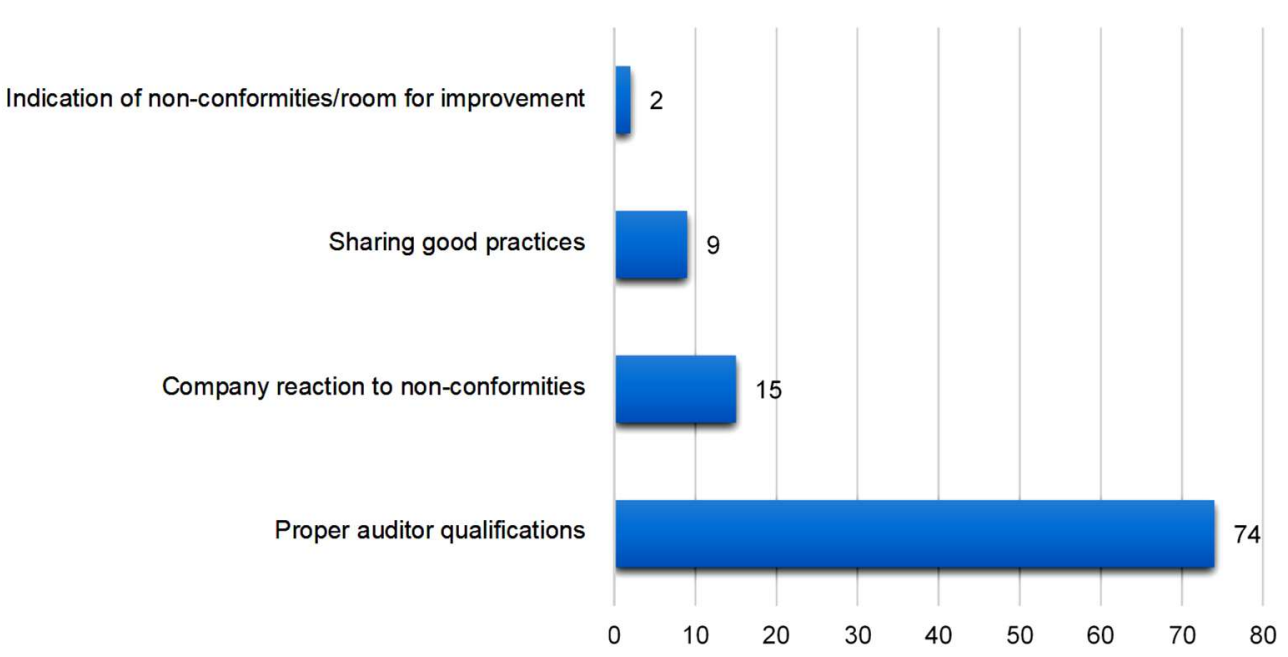

Fig. 2. Percentage share of responses to the question whether an internal audit would bring the added value to the safety management system.

Source: Author's elaboration.

When analysing the above statements, it may be noted that the auditor qualifications are the value that is the most anticipated during an internal audit. Ship crews expect that the auditor would be mainly a person who understands their needs and work specificity. Such an approach should mitigate the risk of misunderstandings during the audit, and its results would affect the systems without extra work and bureaucracy to be performed. Another group of responders $(15 \%)$ indicated the Company reaction to non-conformities. Their expectations are related to the forced Company reaction to the need to implement corrective actions in order to remove the non-conformities found. A part of the responders (9\%) awaits sharing good auditing practices from other ships. They expect that the auditor would provide developed and verified solutions which have been highly assessed both by the auditor, the crew and the Company. The last group of responders includes individuals who perceive an audit as a tool which would the relieve them (work for them). It would mean reporting non-conformities and the interested party would remove them. This attitude is risky due to the fact that an audit is recognised as a tool which would find and report all and any non-conformities. Due to understanding the audit in that manner, there may be a misconception that everything is correct. An auditee is not aware that failing to find non-conformities does not mean that there are not any.

In relation to the audits of safety management, the Company bears liability to designate persons, both ashore and on the ship, who would be responsible for the auditor or an audit team, ensuring necessary measures during the audit, making evidence available and for the cooperation with the auditor in order to achieve the established objectives. An audit is a tool that enables for systematic verification of safety management systems functioning. An internal audit as the first element of the verification is the best tool to find non-conformities and implement corrective 
actions at the stage of the internal control process. If it is used by the Company as a tool to indicate non-conformities, then the stage where the safety system may be improved will not be achieved.

IMO Resolution MSC.273 (85) introduced a number of amendments to the ISM Code, including a major change to clause 1.2.2.2. The clause imposes a requirement to assess the risk on a ship. The ISM Code does not identify any particular approaches to the management of risk, and it is for the shipping companies to choose methods suitable to its organizational structure its ships type and its activities (Sameh and Rashed, 2013). The internal auditor may validate specific activities in terms of the risk, issue an independent and objective opinion on their quality in the scope of functioning on the organisation, but he/she may not be responsible for them.

\section{CONCLUSION}

Audit as a tool to assess management systems functioning on ships is effective and efficient. The condition for achieving efficiency and effectiveness of the audit is that it is carried out by a person properly qualified. That would mean a person having substantive knowledge in regard to the audit scope, who is familiar with and is able to use proper audit techniques. However, it should be borne in mind that the work of qualified auditor does not grant in $100 \%$ that a particular process is functioning correctly, but it allows to ascertain to the Company that the safety systems objectives are achieved. There is one very important matter raised by crews namely losing control and leading to the situation in which ship crew would focus only on the correctness of the provisions to prove that the system functions instead of following the procedures and instructions. High awareness of crew and Company in terms of the system functioning would be anticipated. The safety management systems are mature systems the structure of which is stable and enables for their constant development and improvement. It should be considered to translate the safety management systems scheme into current frame requirements regarding energy efficiency which has been managed based on guidelines. In particular, it appears to be reasonable to use it in the developed internal audit system which is a tool allowing for reliable control of management process in a particular idea. Its specification forces the Company to seek for a newest solution and allows for the application of a number of good practices. The suggested solution is an example of a proven pattern which would be used to develop detailed standards in the scope of ship energy efficiency management.

\section{REFERENCES}

Aae, J.F. Sydnes, A.K. Heggoy, C. (2014). Effects of external audits on safety management systems. A case study of the Norwegian-managed maritime industry. Conference: Proceedings of the European Safety And Reliability Conference (ESREL), Wroclaw, Safety and Reliability. Methodology and Applications, pp. 577-584.

Boveri, A., Silvestro, F., Gualeni, P. (2016). Ship Electrical Load Analysis and Power Generation Optimisation to Reduce Operational Costs, International Conference on Electrical Systems for Aircraft, Railway, Ship Propulsion and Road Vehicles and International Transportation Electrification Conference (ESARS-ITEC), Toulouse.

Hanchrow, G.A. (2017). International Safety Management - Safety Management Systems and the Challenges of Changing a Culture. Transnav - International Journal On Marine Navigation And Safety of Sea Transportation, 11(1), pp. 125-131.

IMO, (1974). International Convention for the Safety of Life at Sea (SOLAS).

IMO, (1995). International Management Code for the Safe Operation of Ships and for Pollution Prevention, Resolution A.741(18) with amendments.

Journal of Laws, (2016). Obwieszczenie Marszałka Sejmu Rzeczypospolitej Polskiej z dnia 29 stycznia 2016 r. w sprawie ogłoszenia jednolitego tekstu ustawy o bezpieczeństwie morskim, Dz. U. 2016 poz. 281 [Journal of Laws of 2016, item 281]

Jurdziński, M. (2013). Planowanie efektywności energetycznej statków morskich, Prace Wydziału Nawigacyjnego w Gdyni, No 28.

Milewska-Zawada, A. (2016). Audyt wewnętrzny szansą na sukces przedsiębiorstwa. Płock: Zeszyty Naukowe PWSZ.

PKN, (2012). PN-EN ISO 19011:2012, Guidelines for auditing management systems.

PRS, (2005). Znowelizowane wytyczne do wdrażania przez administracje Międzynarodowego Kodeksu Zarzadzania Bezpieczeństwem (ISM), Resolution A.913(22). 
PRS, (2006). Zasady certyfikacji systemów zarządzania bezpieczeństwem. Informacje dla armatorów.

Sameh, K. Rashed, (2013). Understanding the risk assessment that recently amended to the ISM Code, Arab Institute of Navigation.

Stanca, C., Stinga, V., Raicu, G. (2015). Improvement opportunities by using remote audit in the maritime transport, 14th International Conference on Informatics in Economy (IE 2015), Bucharest, Education, Research \& Business Technologies, Book Series: International Conference on Informatics in Economy, pp. 418-421.

Date of submission of the article to the Editor: 06/2018

Date of acceptance of the article by the Editor: 09/2018 